\title{
Synthesis of a tricyclic lactone embodying the ABC-ring system of stephaoxocanidine, by tin(IV) chloride-assisted sulfonamidoacetal cyclization and an aromatization promoted by triethylamine
}

\author{
Darío A. Bianchi and Teodoro S. Kaufman* \\ Instituto de Química Orgánica de Síntesis (IQUIOS, CONICET-UNR) and \\ Facultad de Ciencias Bioquímicas y Farmacéuticas, Universidad Nacional de Rosario, \\ Suipacha 531, (S2002LRK) Rosario, Argentina \\ E-mail: tkaufman@fbioyf.unr.edu.ar
}

\begin{abstract}
Dedicated to Professor Edmundo A. Rúveda on the occasion of his $70^{\text {th }}$ birthday and to Professor Roberto A. Rossi on occasion of his $60^{\text {th }}$ birthday
\end{abstract}

(received 30 Jun 03; accepted 25 Aug 03; published on the web 26 Aug 03)

\begin{abstract}
The synthesis of the polysubstituted 8-oxa-1-azaphenalene lactone $\mathbf{4}$, which embodies the ABCring system of stephaoxocanidine, a tetracyclic isoquinoline alkaloid recently isolated from the tubers of Stephania cepharantha Hayata, is reported. Elaboration of $\mathbf{4}$ was carried out by means of the camphorsulfonic acid-assisted lactonization of $\mathbf{9}$, coupled to a titanium(IV) chloridemediated acetal cyclization of the resulting lactone $\mathbf{1 0}$ to form the tricyclic intermediate 12, followed by the base-promoted aromatization of the latter to $\mathbf{1 3}$ and final benzylic bromination. Lactone $\mathbf{4}$ constitutes an advanced key intermediate for the total synthesis of stephaoxocanidine, the simplest stephaoxocane.
\end{abstract}

Keywords: Stephaoxocanidine, natural products, synthesis, isoquinolines, cyclization

\section{Introduction}

The stephaoxocanes constitute a new, small family of isoquinoline alkaloids sharing the tetracyclic stephaoxocane ${ }^{1}$ skeleton (1a). This family, which was independently uncovered during the past decade by Japanese, ${ }^{1}$ Chinese $^{2}$ and Brazilian ${ }^{3}$ research groups, has only five members (1b-1f), all of which have been isolated from Menispermaceæ employed in folk medicine. ${ }^{4}$ The structurally simplest stephaoxocane is stephaoxocanidine (1b), a Stephania cepharantha Hayata alkaloid which contains a fully unsaturated isoquinoline ring system like eletefine (1c), isolated from Cissampelos glaberrima (also known as Cissampelos pareira). 
Other stephaoxocanes such as stephaoxocanine (1d), excentricine (1e) and $N$-methyl excentricine (1f) display their AB-ring systems in the dihydro- and tetrahydro- states, respectively.

Structurally, the stephaoxocanes are reminiscent of other tetracyclic isoquinoline natural products, such as the tropoloisoquinolines [for example: grandirubrine (2a) and imerubrine (3b)] and the azafluoranthenes [for example: rufescine (3a), norrufescine (3b) and imeluteine (3c)]. These are biosynthetically related alkaloids isolated from Menispermaceæ, including C. Pareira, which have shown healing properties as well as interesting cytotoxic and antitumor activities. ${ }^{5}$

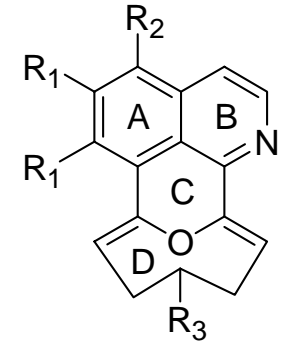

1a $\mathrm{R}_{1}=\mathrm{R}_{2}=\mathrm{R}_{3}=\mathrm{H}$

1b $\mathrm{R}_{1}=\mathrm{OMe}, \mathrm{R}_{2}=\mathrm{H}, \mathrm{R}_{3}=\mathrm{OH}$

1c $\mathrm{R}_{1}=\mathrm{R}_{2}=\mathrm{OMe}, \mathrm{R}_{3}=\mathrm{OH}$

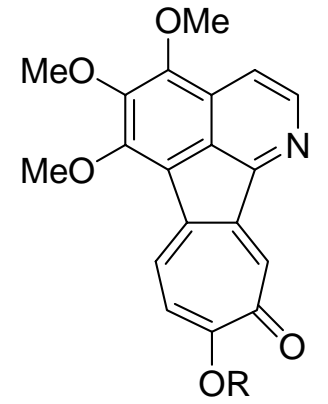

$2 a \mathrm{R}=\mathrm{H}$

2b $\mathrm{R}=\mathrm{Me}$<smiles>COc1cc2c3c(c1OC)C1=NCCC(O1)C3C1CCC2O1</smiles>

1d

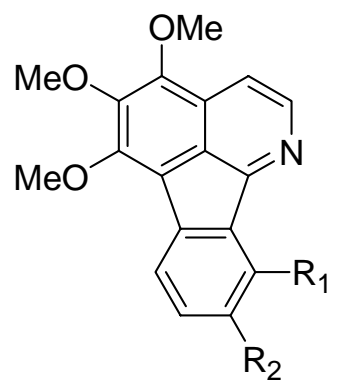

3a $\mathrm{R}_{1}=\mathrm{H}, \mathrm{R}_{2}=\mathrm{OMe}$

3b $\mathrm{R}_{1}=\mathrm{H}, \mathrm{R}_{2}=\mathrm{OH}$

3c $\mathrm{R}_{1}=\mathrm{R}_{2}=\mathrm{OMe}$

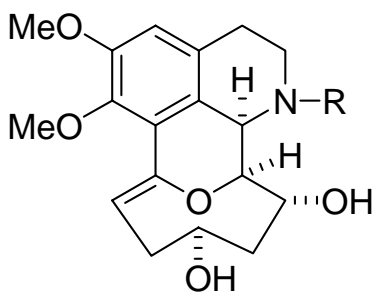

1e $\mathrm{R}=\mathrm{H}$

1f $\mathrm{R}=\mathrm{Me}$

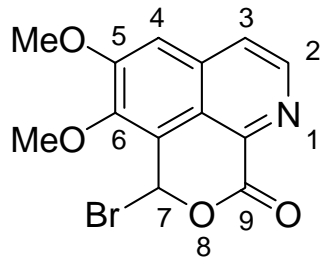

4

We have demonstrated that the cyclization of sulfonamido acetals originally reported by Jackson and coworkers ${ }^{6}$ is a versatile protocol, capable of providing useful intermediates towards polysubstituted isoquinolines, tetrahydroisoquinolines and tetahydroprotoberberines. ${ }^{7}$ In addition, we have recently reported ${ }^{8}$ the synthesis of a tricyclic oxazaphenalene derivative related to the stephaoxocanes, employing a reaction sequence entailing a Friedel-Crafts acylation in association with a benzylic functionalization strategy and a Jackson-type toluenesulfonamide acetal cyclization. ${ }^{6}$

As part of our ongoing project aimed to the synthesis of stephaoxocanes, we describe here the elaboration of polysubstituted 8-oxa-1-azaphenalen-9-one 4 from the previously reported tricarbonylic compound 5, in turn easily accessible from commercially available 2,3dimethoxytoluene. ${ }^{8}$ Tricyclic lactone $\mathbf{4}$ embodies the ABC-ring system of stephaoxocanidine 
(1b) and constitutes a convenient advanced key intermediate for its total synthesis. The 8-oxa-1azaphenalene structure is a new and unprecedented heterocyclic ring system, being this unit unique to the stephaoxocanes.

\section{Results and Discussion}

As shown in Scheme 1, the synthesis commenced with the selective reduction of tricarbonylic compound 5 to mandelate $\mathbf{6}$. Sodium cyanoborohydride proved to be a more appropriate reducing agent than sodium borohydride, which caused partial removal of the acetate, furnishing the benzylic alcohol in $91 \%$ yield. Next, alcohol $\mathbf{6}$ was smoothly and efficiently transformed into the related chloride 7 in $82 \%$ yield by reaction with methanesulfonyl chloride, employing triethylamine as base. ${ }^{9}$ By analogy with similar processes, this transformation most probably proceeded through chloride ion displacement ${ }^{10}$ of a transient mesylate, ${ }^{11}$ which was not isolated.

Benzylic chloride 7 was aminated with aminoacetaldehyde dimethyl acetal in a DMSOtoluene (1:4) solvent mixture, ${ }^{12}$ to which $N$-ethyl diisopropylamine was added as $\mathrm{HCl}$ scavenger, furnishing secondary amine $\mathbf{8}$ in almost quantitative yield. In turn, this was uneventfully converted into the related sulfonamide (9) with tosyl chloride under forcing conditions, ${ }^{8}$ required to overcome the steric crowding surrounding the nitrogen atom.

We have previously reported that submission of $\mathbf{9}$ to Jackson's protocol for 1,2dihydroisoquinoline formation ( $6 \mathrm{~N} \mathrm{HCl}$, dioxane, reflux) resulted only in moderate yields of tetrahydroisoquinoline derivative $\mathbf{1 0}$. We have also recently disclosed that $N$-sulfonyl tetrahydroisoquinolines bearing a carbonyl substituent at C-1 are capable of undergoing aromatization of the heterocyclic ring on exposure to KF supported on alumina under microwave irradiation. ${ }^{13}$ With these precedents in mind, attempts were made to cyclize $\mathbf{9}$ under more efficient, alternative conditions; however, cyclization with $\mathrm{HCl}$ in dioxane to which $\mathrm{EtOH}$ was added ${ }^{14}$ did not yield improved results and reaction of sulfonamido acetal 9 with $\mathrm{SnCl}_{4}$ at $-40^{\circ} \mathrm{C}$ produced only scarce amounts of $\mathbf{1 0}$, together with a complex mixture of decomposition products.

Thus, a stepwise approach towards the desired tricyclic compound was explored, consisting in the elaboration of lactone $\mathbf{1 1}$ as a first step, followed by its subsequent submission to an acetal cyclization protocol and a final B-ring aromatization. Not unexpectedly, however, initial attempts to lactonize 9 either by basic hydrolysis ( $\mathrm{LiOH}, \mathrm{THF} / \mathrm{H}_{2} \mathrm{O}$ and $\mathrm{K}_{2} \mathrm{CO}_{3}, \mathrm{MeOH} / \mathrm{H}_{2} \mathrm{O}$ ) followed by acidic work-up or by transesterification under basic conditions $\left(\mathrm{K}_{2} \mathrm{CO}_{3} \text { in } \mathrm{MeOH}\right)^{15}$ met with failure, probably due to the acidity of the tertiary benzylic proton, which resulted in oxidative desulfonylation of $\mathbf{9}$, with loss of para-toluenesulfinic acid and subsequent hydrolysis of the resulting imine, to yield $\mathbf{5}$. This side reaction is analogous to one previously reported in a similar environment. ${ }^{16}$

Therefore, we turned our attention to an acid catalyzed lactonization process, ${ }^{17}$ which to our delight provided lactone $\mathbf{1 1}$ in 94\% yield, when performed with catalytic amounts of 
camphorsulfonic acid (CSA) in dry methanol. With isochroman-3-one 11 in our hands, exploration of the Lewis acid promoted acetal cyclization was undertaken. However, exposure of 11 to $\mathrm{BF}_{3} \cdot \mathrm{Et}_{2} \mathrm{O}$ during $4 \mathrm{~h}$ at $-78^{\circ} \mathrm{C}$ or $15 \mathrm{~h}$ at $-20^{\circ} \mathrm{C}$ gave no reaction, while running the transformation at $0^{\circ} \mathrm{C}$ resulted in a series of products which decomposed on contact with the silica gel during the chromatographic purification step.<smiles>CCOC(=O)c1ccc(OC)c(OC)c1COC(C)=O</smiles>

5

$\mathrm{MsCl}, \mathrm{Et}_{3} \mathrm{~N}$,

$6 \mathrm{R}=\mathrm{OH}$

AcO

8 $82 \% \longrightarrow 7 \mathrm{R}=\mathrm{Cl}$

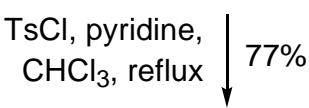

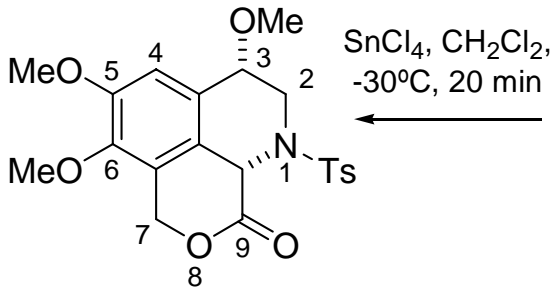

12

$\mathrm{Et}_{3} \mathrm{~N} \downarrow 86 \%, 2$ steps<smiles>COc1cc2ccnc3c2c(c1OC)COC3=O</smiles>

13

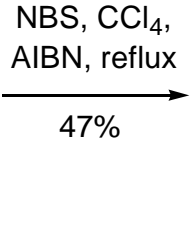

$\underset{47 \%}{\stackrel{\text { AIBN, reflux }}{\longrightarrow}}$

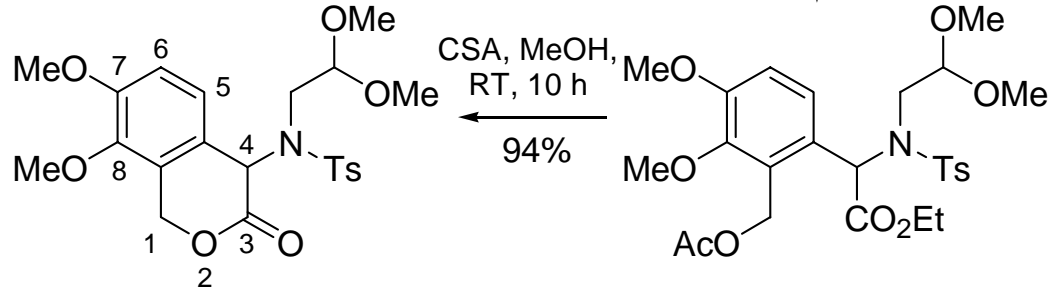

11<smiles>COc1cc2ccnc3c2c(c1OC)C(Br)OC3=O</smiles>

4

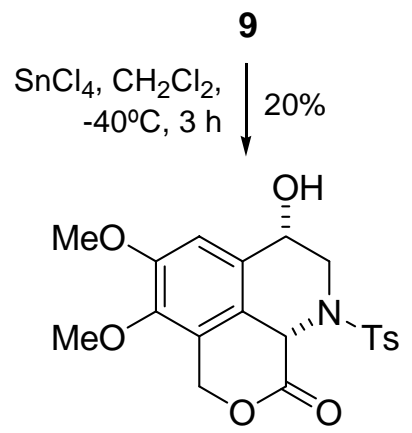

10

\section{Scheme 1}

On the other hand, when the reaction was carried out with 2 equivalents of $\mathrm{SnCl}_{4}$ for $2 \mathrm{~h}$ at $65^{\circ} \mathrm{C}$ or during $20 \mathrm{~min}$ at $-30^{\circ} \mathrm{C}$, smooth and complete cyclization of $\mathbf{1 1}$ to a slightly less polar compound was observed. Interestingly, only one diastereomer was obtained, to which structure 12 was assigned by analogy with previous work $^{8}$ and taking into account the results of differential NOE experiments, showing a $2 \%$ enhancement of the $\mathrm{H}-9$ a signal upon irradiation of $\mathrm{H}-3$, and the coupling constant values $J_{\mathrm{H} 2 \mathrm{ax}-\mathrm{H} 3}=10.1 \mathrm{~Hz}$ and $J_{\mathrm{H} 2 \mathrm{eq}-\mathrm{H} 3}=4.8 \mathrm{~Hz}$. Formation of a single diastereomer is probably due to severe steric restrictions imposed by the 
isochroman-3-one system to the nucleophilic attack of the activated acetal by the aromatic moiety during the cyclization. ${ }^{8}$

In spite that tricyclic compound $\mathbf{1 2}$ tolerated basic work-up, it proved to be unstable and readily decomposed upon contact with silica gel; however, pretreatment of the chromatographic medium with $2 \%$ triethylamine in hexane caused efficient in situ transformation of 12 into oxazaphenalene 13, ${ }^{18}$ this becoming the preferred method for accessing the isoquinoline.

Aromatization of the nitrogen containing heterocyclic ring may be the driving force of this transformation which, as shown in Scheme 2, could probably take place through an initial baseassisted oxidative desulfonylation of $\mathbf{1 2}$ entailing loss of para-toluenesulfinic acid to give intermediate 14, a process favored by the acidity of H-9a. In turn, and after elimination of methanol, 14 would readily provide compound 13, carrying a fully unsaturated AB ring system. The overall transformation is somehow reminiscent of the scarcely employed Pictet-Gams modification of the classical Bischler-Napieralski synthesis, capable of converting $\beta$-hydroxy- or $\beta$-methoxy- phenethylamine derivatives into isoquinolines. ${ }^{19}$

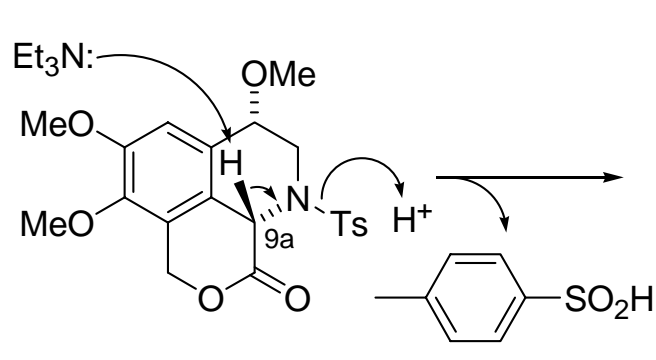

12

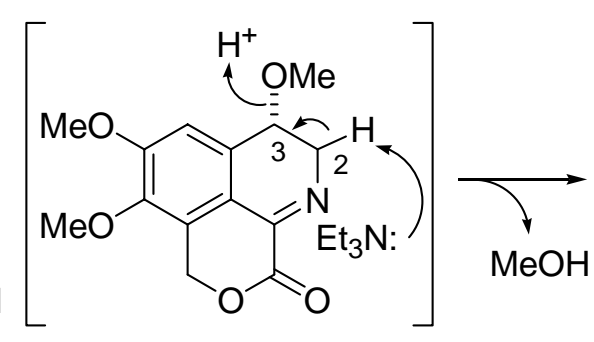

14

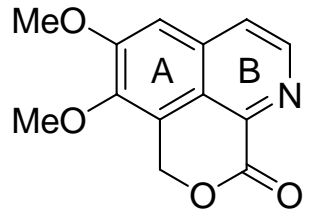

13

\section{Scheme 2}

The proposal that oxidative desulfonylation precedes the loss of methanol during the aromatization is supported by the relatively harsh conditions required to transform $N$-tosyl-1,2dihydroisoquinolines into isoquinolines, ${ }^{13}$ compared to the observed ease with which the basepromoted desulfonylation reaction takes place.

Finally, benzylic bromination of $\mathbf{1 3}$ with NBS in refluxing $\mathrm{CCl}_{4}$, under the assistance of AIBN, furnished brominated derivative $\mathbf{4}$ in moderate but satisfactory yield. ${ }^{20}$ Interestingly, in spite that the benzylic bromination of benzyl ethers has been studied in some detail, ${ }^{21}$ there are only scarce references to the bromination of lactones carrying a benzylic methylene attached to oxygen. ${ }^{22}$ Compound 4 has different C-7 and C-9 functionalities, suitable for the elaboration of the remaining oxocane-type D-ring of stephaoxocanidine. 


\section{Conclusions}

The synthesis of polysubstituted 8-oxa-1-azaphenalene derivative $\mathbf{4}$ was successfully and efficiently achieved in 8 steps and 21\% overall yield from tricarbonylic compound 5. Efficient synthesis and amination of chloride 7, coupled to lactonization of acetate $\mathbf{9}$ prior to acetal cyclization and use of tin(IV) chloride as cyclization promoter proved to be crucial for attaining good yields of tricyclic product 12, while the unusual base-promoted aromatization of 12 was fundamental for accessing oxazaphenalene derivative 13 in good yields. Studies employing 4 as key intermediate for the total synthesis of stephaoxocanidine are under way and will be reported in due time.

\section{Experimental Section}

General Procedures. Melting points were taken on an Ernst Leitz Wetzlar model 350 hot-stage microscope apparatus and are informed uncorrected. FT-IR spectra were determined with Bruker IFS 25 or Beckman Acculab 8 spectrophotometers as thin films held between $\mathrm{NaCl}$ cells or as dispersions in $\mathrm{KBr}$ disks. The ${ }^{1} \mathrm{H}$ and ${ }^{13} \mathrm{C}$-NMR spectra were acquired in $\mathrm{CDCl}_{3}$ employing TMS as internal standard, with a Bruker AC200-E spectrometer operating at 200.13 and $50.33 \mathrm{MHz}$, respectively. DEPT 135 and DEPT 90 experiments aided the interpretation of the fully decoupled ${ }^{13} \mathrm{C}$ NMR spectra. HRMS and microanalytical data were obtained from Kent Electronics (UK), Atlantic Microlab (USA) and UMyMFOR (Argentina). Reactions were carried out under dry Nitrogen or Ar atmospheres, employing oven-dried glassware. Commercially obtained reagents were used without further purification. Dry THF and toluene were prepared by distillation from Na-benzophenone ketyl; anhydrous DMSO, $N$-ethyl diisopropylamine and $\mathrm{Et}_{3} \mathrm{~N}$ were accessed by reflux and distillation from $\mathrm{CaH}_{2} ; \mathrm{CHCl}_{3}$ and $\mathrm{CH}_{2} \mathrm{Cl}_{2}$ were distilled from $\mathrm{P}_{2} \mathrm{O}_{5}$ and pyridine was dried over $\mathrm{KOH}$ pellets and then distilled; anhydrous solvents were stored in dry Schlenk bottles. All new compounds gave single spots on TLC plates run in different solvent systems. Spots were visualized by exposure to UV light (254 and $365 \mathrm{~nm}$ ), followed by spraying with ethanolic $p$-anisaldehyde/sulfuric acid reagent and careful heating. Standard work-up procedures consisted in diluting the reaction with brine $(5-20 \mathrm{~mL})$ and extracting the products with EtOAc ( 3 x $20-40 \mathrm{~mL}$ ); the combined organic extracts were washed once with brine, dried over $\mathrm{Na}_{2} \mathrm{SO}_{4}$, concentrated under reduced pressure and the respective residues were chromatographed. Flash column chromatographies were carried out with silica gel $60 \mathrm{H}$, eluting with hexaneEtOAc mixtures under positive pressure and employing gradient techniques. Mixtures of EtOAcacetone and EtOAc-EtOH were used for the separation of $\mathbf{4}$ and 13, respectively.

Ethyl\{2-[(acetoxy)methyl]-3,4-dimethoxyphenyl\}-(hydroxy)acetate (6). A solution of keto ester 5 (1001.4 mg, $3.23 \mathrm{mmol})$ in absolute ethanol (40 mL) was successively treated with glacial acetic acid (0.184 mL, $3.23 \mathrm{mmol}$ ) and sodium cyanoborohydride (223.7 mg, $3.55 \mathrm{mmol}$ ), and 
the mixture was stirred overnight at room temperature. The reaction was quenched with $1 \mathrm{~N}$ $\mathrm{NaOH}(5 \mathrm{~mL}$ ) and submitted to the conventional work-up procedure, providing mandelate 6 (918 mg, 91 \%), as an oil; IR (film): 3460, 2980, 2850, 1750, 1740, 1600, 1500, 1460, 1280, 1090 and $810 \mathrm{~cm}^{-1}$; ${ }^{1} \mathrm{H}$ NMR ( $)$ ): 1.22 (t, $3 \mathrm{H}, J=7.1, \mathrm{OCH}_{2} \mathrm{Me}$ ), 1.57 (bs, $\mathrm{w}_{1 / 2}=10 \mathrm{~Hz}, 1 \mathrm{H}, \mathrm{OH}$ ), 2.07 (s, $3 \mathrm{H}, \mathrm{MeCO}_{2}$ ), 3.84 (s, $3 \mathrm{H}, \mathrm{OMe}$ ), 3.86 (s, $3 \mathrm{H}, \mathrm{OMe}$ ), 4.20 (dq, $2 \mathrm{H}, J=1.0$, 7.1, $\mathrm{OCH}_{2} \mathrm{Me}$ ), 5.35 (s, $2 \mathrm{H}, \mathrm{ArCH}_{2} \mathrm{O}$ ), 5.40 (s, $\left.1 \mathrm{H}, \mathrm{ArCHOH}\right), 6.92$ (d, $\left.1 \mathrm{H}, J=8.6, \mathrm{H}-5\right)$ and 7.10 (d, $1 \mathrm{H}, J=$

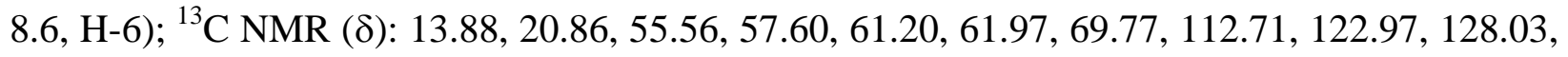
130.88, 148.46, 142.65, 170.73 and 173.60. HRMS $\mathrm{m} / \mathrm{z}$ 312.12118; $\mathrm{C}_{15} \mathrm{H}_{20} \mathrm{O}_{7}$ requires 312.12087.

Ethyl \{2-[(acetyloxy)methyl]-3,4-dimethoxyphenyl\}[N-(2,2-dimethoxyethyl)amino]acetate (8). Triethylamine (1.66 mL, $11.97 \mathrm{mmol}$ ) was added to an ice-cooled solution of mandelate 6 (931 $\mathrm{mg}, 2.99 \mathrm{mmol})$ in $\mathrm{CH}_{2} \mathrm{Cl}_{2}(25 \mathrm{~mL})$ and the resulting solution was treated dropwise with a freshly prepared solution of methanesulfonyl chloride $(0.697 \mathrm{~mL}, 8.98 \mathrm{mmol})$ in $\mathrm{CH}_{2} \mathrm{Cl}_{2}(5 \mathrm{~mL})$. After stirring overnight, the reaction was submitted to the conventional work-up procedure, furnishing chloride 7 (809 mg, $82 \%$ ) as a clear, slightly unstable oil. IR (film): 2982, 2941, 1748, 1735, 1683, 1583, 1497, 1378, 1323, 1288, 1177, 1086 and $978 \mathrm{~cm}^{-1} ;{ }^{1} \mathrm{H}$ NMR $(\delta): 1.26$ (t, $3 \mathrm{H}, J=7.1, \mathrm{OCH}_{2} \mathrm{Me}$ ), 2.08 (s, $3 \mathrm{H}, \mathrm{MeCO}_{2}$ ), 3.86 (s, $3 \mathrm{H}, \mathrm{OMe}$ ), 3.87 (s, $3 \mathrm{H}, \mathrm{OMe}$ ), 4.19 (dq, $2 \mathrm{H}, J=7.1, \mathrm{OCH}_{2} \mathrm{Me}$ ), 5.29 (d, $1 \mathrm{H}, J=12.2$, $\mathrm{ArCH}_{2} \mathrm{O}$ ), 5.37 (d. $1 \mathrm{H}, J=12.2, \mathrm{ArCH}_{2} \mathrm{O}$ ), 5.66 (s, $1 \mathrm{H}, \mathrm{ArCHCl}$ ), 6.96 (d, $1 \mathrm{H}, J=8.8, \mathrm{H}-5$ ) and 7.38 (d, $1 \mathrm{H}, J=8.8, \mathrm{H}-6) ;{ }^{13} \mathrm{C}$ NMR (8): 13.79, 20.70, 55.10, 55.60, 57.21, 61.22, 62.29, 112.95, 124.53, 127.90, 128.34, 147.98, 153.11, 168.22 and 170.41. Without delay, chloride 7 was dissolved in a mixture of DMSO (5 mL) and toluene (20 mL), to which $N$-ethyl diisopropylamine $(3.82 \mathrm{~mL}, 21.99 \mathrm{mmol})$ and aminoacetaldehyde dimethyl acetal $(0.798 \mathrm{~mL}, 7.33 \mathrm{mmol})$ were successively added. The reaction was warmed to $60^{\circ} \mathrm{C}$ and stirred overnight until completion. Submission of the mixture to conventional work-up conditions gave secondary amine 8 (954 mg, $98 \%$ ), as a clear oil. IR (film): 3550-2700, 2960, 2840, 1740, 1280, 1090 and $820 \mathrm{~cm}^{-1}$; ${ }^{1} \mathrm{H}$ NMR ( $\delta$ ): 1.20 (t, $3 \mathrm{H}, J=7.1, \mathrm{OCH}_{2} \mathrm{Me}$ ), 1.92 (bs, 1 $\mathrm{H}, \mathrm{NH}$ ), 2.05 (s, $3 \mathrm{H}, \mathrm{MeCO}_{2}$ ), 2.59 (dd, $1 \mathrm{H}, J=5.5,13.0, \mathrm{NCH}_{2}$ ), 2.74 (dd, $1 \mathrm{H}, J=5.5,13.0$, $\mathrm{NCH}_{2}$ ), 3.34 (s, $3 \mathrm{H}, \mathrm{CHOMe}$ ), 3.36 (s, $3 \mathrm{H}, \mathrm{CHOMe}$ ), 3.85 (s, 3 H, OMe), 3.86 (s, $3 \mathrm{H}, \mathrm{OMe}$ ), $4.13\left(\mathrm{dq}, 2 \mathrm{H}, J=1.0,7.1, \mathrm{OCH}_{2} \mathrm{Me}\right), 4.46\left[\mathrm{t}, 1 \mathrm{H}, J=5.5, \mathrm{CH}(\mathrm{OMe})_{2}\right], 4.61(\mathrm{~s}, 1 \mathrm{H}$, $\mathrm{ArCHCO}_{2} \mathrm{Et}$ ), 5.34 (s, $2 \mathrm{H}, \mathrm{ArCH}_{2} \mathrm{O}$ ), 6.89 (d, $1 \mathrm{H}, J=8.6, \mathrm{H}-5$ ) and 7.10 (d, $\left.1 \mathrm{H}, J=8.6, \mathrm{H}-6\right)$; ${ }^{13} \mathrm{C}$ NMR (ס): 13.95, 20.86, 48.82, 53.46, 53.73, 55.59, 57.59, 60.76, 60.99, 61.22, 103.72, 112.78, 122.53, 128.38, 130.67, 148.42, 152.23, 170.65 and 172.72; HRMS m/z 399.1904; $\mathrm{C}_{19} \mathrm{H}_{29} \mathrm{NO}_{8}$ requires 399.1893 .

Ethyl \{2-[(acetyloxy)methyl]- 3,4-dimethoxyphenyl]- $\{N$-(2,2-dimethoxyethyl)- $N$-(4-methyl phenyl)sulfonyl]-amino\}-acetate (9). Toluene-p-sulfonyl chloride (1133 mg, $5.94 \mathrm{mmol}$ ) was added all at once to a solution of amine $8(947 \mathrm{mg}, 2.38 \mathrm{mmol})$ in a mixture of dry chloroform $(25 \mathrm{~mL})$ and pyridine $(0.862 \mathrm{~mL}, 10.69 \mathrm{mmol})$. The reaction was refluxed for $16 \mathrm{~h}$ and then it was submitted to the standard work-up protocol, providing sulfonamide 9 (1064 $\mathrm{mg}, 81 \%$ ), as a solid $\mathrm{mp}$ 88.5-90 ${ }^{\circ} \mathrm{C}$ (hexane-EtOAc); IR (KBr): 2940, 2840, 1740, 1600, 1500, 1460, 1350, 1290, 1170, 1090, 1080, 830 and $670 \mathrm{~cm}^{-1}$; ${ }^{1} \mathrm{H}$ NMR $(\delta): 1.14$ (t, $3 \mathrm{H}, J=7.2, \mathrm{OCH}_{2} \mathrm{Me}$ ), 2.11 (s, 
$3 \mathrm{H}, \mathrm{MeCO}_{2}$ ), 2.44 (s, $3 \mathrm{H}, \mathrm{ArMe}$ ), 3.01 (s, $3 \mathrm{H}, \mathrm{OMe}$ ), 3.21 (s, $3 \mathrm{H}, \mathrm{OMe}$ ), 3.26 (dd, $1 \mathrm{H}, J=$ 6.9, 15.7, $\mathrm{NCH}_{2}$ ), 3.49 (dd, $1 \mathrm{H}, J=4.0,15.7, \mathrm{NCH}_{2}$ ), 3.85 (s, $3 \mathrm{H}, \mathrm{OMe}$ ), 3.86 (s, $3 \mathrm{H}, \mathrm{OMe}$ ), 3.82-4.10 (m, $3 \mathrm{H}, \mathrm{NCH}_{2} \mathrm{CH}$ and $\left.\mathrm{OCH}_{2} \mathrm{Me}\right), 5.13$ (d, $\left.1 \mathrm{H}, J=11.9, \mathrm{ArCH}_{2} \mathrm{O}\right), 5.40$ (d, $1 \mathrm{H}, J=$ 11.9, $\mathrm{ArCH}_{2} \mathrm{O}$ ), 6.07 (s, $\left.1 \mathrm{H}, \mathrm{ArCHNTs}\right), 6.77$ (d, $1 \mathrm{H}, J=8.6, \mathrm{H}-5$ ), 6.85 (d, $1 \mathrm{H}, J=8.6, \mathrm{H}-6$ ), 7.29 (d, $2 \mathrm{H}, J=8.3$, ArH of tosyl) and 7.72 (d, $2 \mathrm{H}, J=8.3$, ArH of tosyl); ${ }^{13} \mathrm{C}$ NMR ( $\delta$ ): 13.75 , 20.92, 21.94, 47.44, 54.48, 54.93, 55.56, 57.50, 59.97, 61.15, 61.20, 104.37, 111.83, 124.70, 125.91, 127.65, 129.26, 130.41, 135.78, 143.55, 146.91, 153.32, 170.11 and 170.52; Anal. Calcd. for $\mathrm{C}_{26} \mathrm{H}_{35} \mathrm{NO}_{10} \mathrm{~S}$ : C, 56.41; H, 6.37; N, 2.53; S, 5.79. Found: C, 56.53; H, 6.34; N, 2.55; S, 5.83. $N$-(2,2-Dimethoxyethyl)-4-methyl- $N$-(3-oxo-3,4-dihydro-7,8-dimethoxy-1H-isochromen-4yl) -benzenesulfonamide (11). A solution of acetate 9 (734 mg, $1.33 \mathrm{mmol}$ ) in dry methanol (20 $\mathrm{mL}$ ) was treated with camphorsulfonic acid (154.2 $\mathrm{mg}, 0.66 \mathrm{mmol}$ ) and the reaction was stirred at room temperature until complete disappearance of the starting material (10 h). Then, most of the solvent was removed under reduced pressure and the residue was submitted to the conventional work-up procedure, furnishing isochroman-3-one 11 (580 mg, $94 \%$ ), as a white solid mp 123-125ㄷ (hexane-EtOAc). IR (KBr): 2940, 2850, 1750, 1610, 1500, 1460, 1320,

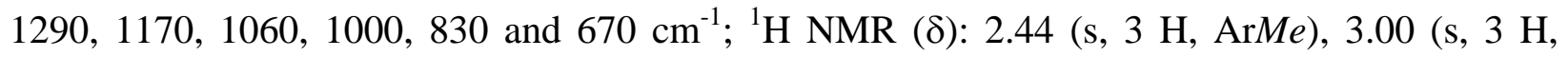
CHOMe), 3.17 (dd, $1 \mathrm{H}, J=5.7,15.2, \mathrm{CH}_{2} \mathrm{CH}$ ), 3.17 (s, $3 \mathrm{H}, \mathrm{CHOMe}$ ), 3.42 (dd, $1 \mathrm{H}, J=4.7$, 15.2, $\mathrm{CH}_{2} \mathrm{CH}$ ), 3.66 (s, $3 \mathrm{H}, \mathrm{OMe}$ ), 3.67 (s, $3 \mathrm{H}, \mathrm{OMe}$ ), 4.16 (dd, $1 \mathrm{H}, J=4.7,5.7, \mathrm{CH}_{2} \mathrm{CH}$ ), 5.33 (d, $1 \mathrm{H}, J=15.6, \mathrm{ArCH}_{2}$ ), 5.52 (d, $1 \mathrm{H}, J=15.6, \mathrm{ArCH}_{2}$ ), 5.87 (s, $1 \mathrm{H}, \mathrm{ArCHCO}_{2}$ ), 6.94 (d, $1 \mathrm{H}$, $J=8.6, \mathrm{H}-6$ ), 7.14 (d, $1 \mathrm{H}, J=8.6, \mathrm{H}-5), 7.32$ (d, $2 \mathrm{H}, J=8.1$, ArH of tosyl) and 7.90 (d, $2 \mathrm{H}, J=$ 8.1, ArH of tosyl); ${ }^{13} \mathrm{C}$ NMR ( $)$ : 21.46, 47.29, 53.94, 54.23, 55.78, 56.18, 60.54, 65.93, 103.26, 112.69, 122.30, 122.64, 124.48, 127.88, 129.40, 136.76, 143.64, 151.42 and 167.67. Anal. Calcd. for $\mathrm{C}_{22} \mathrm{H}_{27} \mathrm{NO}_{8} \mathrm{~S}$ : C, 56.76; H, 5.85; N, 3.01; S, 6.89. Found: C, 56.83; H, 5.80; N, 2.95; S, 6.93.

5,6-Dimethoxy-7H,9H-pyrano[3,4,5-ij]isoquinolin-9-one (13). A freshly prepared solution of $\mathrm{SnCl}_{4}$ in $\mathrm{CH}_{2} \mathrm{Cl}_{2}(6.5 \mathrm{~mL}, 2.61 \mathrm{mmol}$ ) was added dropwise to sulfonyl acetal 11 (578 mg, 1.24 mmol) was dissolved in dry $\mathrm{CH}_{2} \mathrm{Cl}_{2}(14 \mathrm{~mL})$ and cooled to $-30^{\circ} \mathrm{C}$. The resulting yellow mixture was stirred $20 \mathrm{~min}$ at $-30^{\circ} \mathrm{C}$, then it was quenched with saturated $\mathrm{NaHCO}_{3}$ solution $(5 \mathrm{~mL})$ and subjected to the conventional extractive work-up procedure, affording a crude consisting essentially in the unstable sulfonamide 12. ${ }^{1} \mathrm{H}$ NMR ( $\delta$ ): 2.44 (s, $3 \mathrm{H}$, ArMe), 2.66 (dd, $1 \mathrm{H}, J=$ 10.1, 13.3, H-2 ax), 3.58 (s, 3 H, CHOMe), 3.86 (s, 3 H, OMe), 3.89 (s, 3 H, OMe), 4.14 (dd, 1 H, $J=4.8,13.3, \mathrm{H}-2_{\text {eq }}$ ), 4.39 (dd, $1 \mathrm{H}, J=4.8,10.1, \mathrm{H}-3$ ), 5.26 (d, $1 \mathrm{H}, J=14.1, \mathrm{H}-7$ ax), 5.55 (s, 1 H, H-9a), 5.59 (d, 1 H, J= 14.1, H-7eq), 7.12 (s, 1 H, H-4), 7.34 (d, 2 H, J= 8.2, ArH of tosyl) and

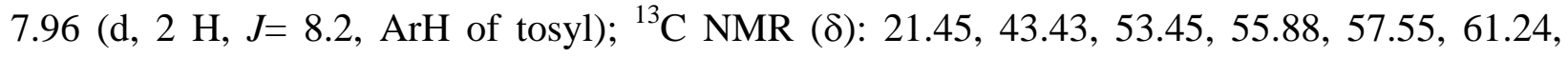
64.25, 73.29, 109.47, 118.50, 124.44, 127.82, 129.53, 132.08, 136.64, 143.86, 144.87, 152.00 and 168.92. Submission of the crude reaction product to chromatography on a silica gel column pre-treated with 2\% $\mathrm{Et}_{3} \mathrm{~N}$ in hexane, afforded oxazaphenalene lactone 13 (263 mg, 86\%), as white needles mp 222-223ㅇ (EtOH-EtOAc); IR (KBr): 2950, 2920, 1745, 1630, 1590, 1475,

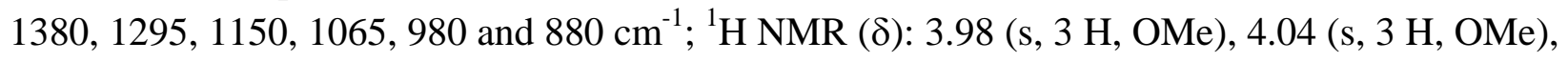
5.85 (s, 2 H, H-7), 7.15 (s, 1 H, H-4), 7.71 (d, 1 H, J= 5.6, H-3) and 8.72 (d, $1 \mathrm{H}, J=5.6, \mathrm{H}-2$ );

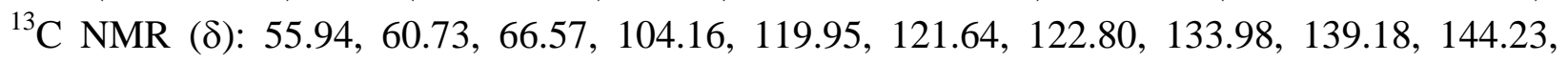


145.12, 156.12 and 161.24. Anal. Calcd. for $\mathrm{C}_{13} \mathrm{H}_{11} \mathrm{NO}_{4}$ : C, 63.67; H, 4.52; N, 5.71. Found: C, 63.63; H, 4.57; N, 5.69.

7-Bromo-5,6-dimethoxy-7H,9H-pyrano[3,4,5-ij]isoquinolin-9-one (4). To a solution of 13 (16 $\mathrm{mg}, 0.065 \mathrm{mmol})$ in $\mathrm{CCl}_{4}(2 \mathrm{~mL})$ were successively added NBS (12.1 mg, $\left.0.068 \mathrm{mmol}\right)$ and a $0.015 \mathrm{M}$ solution of $\mathrm{AIBN}(0.2 \mathrm{~mL}, 0.003 \mathrm{mmol})$ in $\mathrm{CCl}_{4}$, and the resulting mixture was gently refluxed during $2.5 \mathrm{~h}$. Then, the reaction was submitted to the standard work-up procedure, providing 4 (10.1 mg, 47\%), as a white solid (EtOAc) $\mathrm{mp}>300^{\circ} \mathrm{C}$ (with decomposition). IR (KBr): 2900, 1730, 1620, 1580, 1480, 1350, 1280, 1190, 1030, 990, 875, 750 and $680 \mathrm{~cm}^{-1} ;{ }^{1} \mathrm{H}$

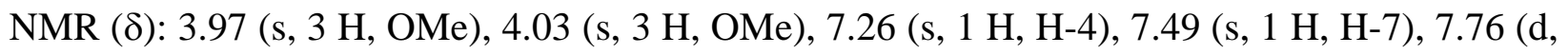
$1 \mathrm{H}, J=5.5, \mathrm{H}-3$ ) and 8.77 (d, $1 \mathrm{H}, J=5.5, \mathrm{H}-2)$; ${ }^{13} \mathrm{C} \mathrm{NMR}(\delta): 56.04,60.99,74.80,85.98$, 106.03, 117.35, 122.95, 133.22, 144.19, 155.82 and 174.39. HRMS m/z 322.9797 $\mathrm{C}_{13} \mathrm{H}_{10} \mathrm{BrNO}_{4}$ requires 322.9793 .

\section{Acknowledgments}

The authors gratefully acknowledge CONICET, ANPCyT, SECyT-UNR and Fundación Antorchas for generous financial support. D.A.B. thanks CONICET for a Doctoral Fellowship.

\section{References}

1. (a) Kashiwaba, N.; Morooka, S.; Kimura, M.; Ono, M. J. Nat. Prod. 1996, 59, 803. (b) Kashiwaba, N.; Morooka, S.; Kimura, M.; Ono, M.; Toda, J.; Suzuki, H.; Sano, T. Nat. Prod. Lett. 1997, 9, 177.

2. (a) Deng, J.-Z.; Zhao, S.-X.; Miao, Z.-Ch. Nat. Prod. Lett. 1993, 2, 283. (b) Deng, J.-Z.; Zhao, S.-X. J. Nat. Prod. 1997, 60, 294.

3. da-Cunha, E. V. L.; Cornélio, M. L.; Barbosa-Filho, J. M.; Braz-Filho, R.; Gray, A. I. J. Nat. Prod. 1998, 61, 1140.

4. (a) Pío-Corrêa, M. In Dicionário das Plantas Úteis do Brasil e das Exóticas Cultivadas; Ministério da Agricultura: Rio de Janeiro, Brazil, Ed., 1984, Vol. 2, p 282. (b) Nawawi, A.; Ma, C.; Nakamura, N.; Hattori, M.; Kurokawa, M.; Shiraki, K.; Kashiwaba, N.; Ono, M. Biol. Pharm. Bull. 1999, 22, 268. (c) Zhong-yao-dai-ci-dian (Dictionary of Chinese Crude Drugs). Chiang Su New Medicine College, Ed.; Shanghai Scientific Technologic Publisher, Shanghai, China, 1978,; p 2141. (d) Makidono, R.; Makidono, A.; Matsuura, K. Nippon Acta Radiologica 1977, 37, 1153.

5. (a) Buck, K. T. Azafluoranthene and Tropoloisoquinoline Alkaloids. In The Alkaloids, Brossi, A. Ed.; Academic Press, Inc.; New York: 1984; Vol. 23, pp 303-325. (b) Paris, R. R.; Moyse, H. In Matiere Medicale; Masson: Paris, 1967; Vol. 2, p 178. (c) Lewis, W. H.; Stonard, R. J.; Porras-Reyes, B.; Mustoe, T. A. U. S. Patent 5, 156, 847, 1992; Chem. Abstr. 
1992, 117, 245630t. (d) For a proposal on the formation of azafluoranthene alkaloids from tropoloisoquinolines, see: Silverton, J. V.; Kabuto, C.; Buck, K. T.; Cava, M. P. J. Am. Chem. Soc. 1977, 99, 6708.

6. (a) Jackson, A. H.; Stewart, G. W. J. Chem. Soc., Chem. Commun. 1971, 149. (b) Charnock, S. A.; Jackson, A. H.; Martin, J. A.; Stewart, G. W. J. Chem. Soc., Perkin Trans. 1 1974, 1911. (c) Birch, A. J.; Jackson, A. H.; Shannon, P. V. R. J. Chem. Soc., Perkin Trans. 1 1974, 2185.

7. (a) Bianchi, D. A.; Kaufman, T. S. Can. J. Chem. 2000, 78, 1165. (b) Kaufman, T. S. Molecules 2000, 5, 491. (c) Larghi, E. L.; Kaufman, T. S. Tetrahedron Lett. 1997, 38, 3159. (d) Ponzo, V. L.; Kaufman, T. S. J. Chem. Soc., Perkin Trans. 1 1997, 3131. (e) Ponzo, V. L.; Kaufman, T. S. Tetrahedron Lett. 1995, 36, 9105.

8. Kaufman, T. S. Heterocycles 2001, 55, 323.

9. (a) Collington, E. W.; Meyers, A. I. J. Org. Chem. 1971, 36, 3044. (b) Hwang, C. K.; Li, W. S.; Nicolau, K. C. Tetrahedron Lett. 1984, 2295.

10. (a) Snyder, D. C. J. Org. Chem. 1995, 60, 2638. (b) Munyemana, F.; Frisque-Hesbain, A.M.; Devos, A.; Ghosez, L. Tetrahedron Lett. 1989, 30, 3077. (c) De Luca, L.; Giacomelli, G.; Porcheddu, A. Org. Lett. 2002, 4, 553. (d) Yoshida, Y.; Sakakura, Y.; Aso, N.; Okada, S.; Tanabe, Y. Tetrahedron 1999, 55, 2183.

11. Crossland, R. K.; Servis, K. L. J. Org. Chem. 1970, 35, 3195.

12. (a) Uenishi, J.; Tomoko, T.; Ueno, T.; Hiraoka, T.; Yonemitsu, O.; Tsukube, H. Synlett 1999, 41. (b) Hrubiec, R. T.; Smith, M. B. Tetrahedron Lett. 1983, 24, 5031. (c) Jones, T. K.; Mohan, J. J.; Xavier, L. C.; Blacklock, T. J.; Mathre, D. J.; Sohar, P.; Turner-Jones, R. T.; Reamer, R. A.; Roberts, F. E.; Grabowski, E. J. J. J. Org. Chem. 1991, 56, 763. (d) Du Priest, M. T.; Zinke, P. W.; Conrow, R. E.; Kuzmich, D.; Dantanarayana, A. P.; Sproull, S. J. J. Org. Chem. 1997, 62, 9372.

13. (a) Silveira, C. C.; Bernardi, C. R.; Braga, A. L.; Kaufman, T. S. Synlett 2002, 906. (b) Silveira, C. C.; Bernardi, C. R.; Braga, A. L.; Kaufman, T. S. Tetrahedron Lett. 2001, 42, 8947.

14. (a) MacLean, D. B.; Cundasawmy, N. E. Can. J. Chem. 1972, 50, 3028. (b) Nagata, H.; Miyazawa, N.; Ogasawara, K. J. Chem. Soc., Chem. Commun. 2001, 1094.

15. (a) Hori, K.; Hikage, N.; Inagaki, A.; Mori, S.; Nomura, K.; Yoshii, E. J. Org. Chem. 1992, 57, 2888. (b) Castagnani, R.; De Angelis, R.; De Fusco, E.; Gianessi, F.; Misiti, D.; Meloni, D.; Tinti, M. O. J. Org. Chem. 1995, 60, 8318.

16. Ponzo, V. L.; Kaufman, T. S. Tetrahedron Lett. 1995, 36, 9105.

17. (a) Taylor, S. K.; Fried, J. A.; Grassi, Y. N.; Marolewski, A. E.; Pelton, E. A.; Poel, T.-J.; Rezanka, D. S.; Whittaker, M. R. J. Org. Chem. 1993, 58, 7304. (b) Konoike, T.; Araki, Y. J. Org. Chem. 1994, 59, 7849.

18. Preliminary assays demonstrated that compound $\mathbf{1 3}$ is a potent acetylcholinesterase inhibitor, with $\mathrm{IC}_{50}=23 \mu \mathrm{M}$.

19. (a) Whaley, W. M.; Govindachari, T. R. Org. React. 1951, 6, 74. (b) Herz, W.; Tsai, L. J. 
Am. Chem. Soc. 1955, 77, 3529. (c) Biandra, A. A.; Wadia, M. S.; Dutta, N. L. Tetrahedron Lett. 1968, 2677.

20. (a) Dubey, S. K.; Kumar, S. J. Org. Chem. 1986, 51, 3407. (b) Pizey, J. S. In Synthetic Reagents, J. Wiley \& Sons: New York, 1974, Vol. 2, pp 15-21.

21. (a) Lovins, R. E.; Andrews, L. J.; Keefer, R. M. J. Org. Chem. 1963, 28, 2847. (b) Lovins, R. E.; Andrews, L. J.; Keefer, R. M. J. Org. Chem. 1965, 30, 1577.

22. Blair, J.; Logan, W. R.; Newbold, G. T. J. Chem. Soc. 1956, 2443. 